\title{
Wonder Woman: An Assemblage of Complete Virtue Packed in a Tight Swimsuit
}

\author{
Theresa Ashford ${ }^{1}$ \\ University of the Sunshine Coast, Australia \\ Neal Curtis ${ }^{2}$ \\ The University of Auckland, New Zealand
}

\begin{abstract}
This paper uses actor-network theory (ANT) and Aristotelian virtue ethics to think with/of Wonder Woman as an assemblage of human and non-human actors clustered on a page. It also considers how the emerging assemblage that is Wonder Woman might be viewed as the embodiment of Aristotle's 'complete virtue' or justice. As one of the 'trinity' of Detective Comics (DC) superheros, which also include Superman and Batman, Wonder Woman was created to counter the sadism and tyranny of the Nazi threat during the 1930s and 1940s and has been continually published since 1941 . Wonder Woman is a multidimensional icon and an exemplary model of a superhero with a different body and voice, who operates in a different way in the world. She is presented here as a case study to trace possible translations of Aristotle's configurations of virtue and justice. Using ANT, we argue that Wonder Woman arises from an assemblage of actors that include an armoured swimsuit, a magic lasso, shiny bracelets and a star-emblazoned tiara. By problematising these technologies as actors that commonly invite objectification (the swimsuit) or subjugation (the ropes), this paper suggests possible divergent readings that reveal how virtue and justice can emerge within these relational networks. We test how the sexualised body depictions and overt bondage references in the Wonder Woman comics, and in particular, in our chosen story, George Pérez's Wonder Woman: Destiny Calling, offer something bolder and more profound-a complex performance of justice. Additionally, this paper intimates the productive methodological powers of ANT in relation to the broader field of comics studies.
\end{abstract}

Keywords: Virtue theory; Wonder Woman; actor-network theory (ANT); justice; superheroes.

\section{Introduction}

This paper uses the actor-network theory (ANT) and Aristotelian virtue ethics to think with/of Wonder Woman as an assemblage of human and non-human actors clustered on a page. It also considers how the emerging assemblage that is Wonder Woman might be viewed as the embodiment of Aristotle's 'complete virtue' or justice. As one of the 'trinity' of Detective Comics (DC) superheros, which also includes Superman and Batman, Wonder Woman was created to counter the sadism and tyranny of the Nazi threat during the 1930s and 1940s and has been published continually since 1941. Wonder Woman is a multidimensional icon and an exemplary model of a superhero with a different body and voice, who operates in a different way in the world. ${ }^{3}$ We argue that Wonder Woman arises from a network of actors that include an armoured swimsuit, a magic lasso, shiny bracelets and a star-emblazoned tiara. By problematising these technologies as actors that commonly invite objectification (the swimsuit) or subjugation (the ropes), this paper suggests possible divergent readings that reveal how virtue and justice can emerge within these relational networks. We test how the sexualised body depictions and overt bondage references in the Wonder Woman comics and in particular, in our chosen story, George Pérez's Wonder Woman: Destiny Calling, offer something bolder and more profound-a complex performance of justice.

\footnotetext{
${ }^{1}$ Lecturer, School of Law and Society, the University of the Sunshine Coast, Queensland, Australia. https://orcid.org/0000-0002-5135-6766

${ }^{2}$ Associate Professor, Media and Communication, The University of Auckland, New Zealand.

${ }^{3}$ See Carol Gilligan's work In a Different Voice in which she flips ideas of women's weaknesses and demonstrates that they are strengths.
}

Except where otherwise noted, content in this journal is licensed under a Creative Commons Attribution 4.0 International Licence. As an open access journal, articles are free to use with proper attribution. ISSN: 2652-4074 (Online) 
In a broader context, this paper offers a socio-material approach to comics themselves as generative acts of translation. Comics are co-created by complex networks of writers, artists, trees, comic fans, ink, publishing machines, long nights, comic histories, copyright laws, distribution lines, moral codes and evolving cultural contexts. It is important to note that comics are also transmedia objects. At the time of Wonder Woman's creation, comics emerged through relations with newspapers, radio, cinema, magazines and pulp fiction and were fed by the stories that flowed through these mediums. Comic actors enacted scripts on gender, nationalism, war, moral sensibilities, sexuality, reproductive rights and suffrage. Thomas Giddens (2018) described comics as a 'multimodal' medium that:

... employs, exploits, or presents a variety of different modes of communicating — visual, textual, graphic, linguistic, spatial, narrational-in a complex layering of multiple frames. This 'multiframe' has sophisticated aesthetic and formal rules that can be enforced, played with, or rejected to different ends. ${ }^{4}$

The broader implications of using ANT as a method to study the medium of comics itself is a separate project that requires further attention. In this paper, we follow and extend this approach by mischievously using ANT to help us break normative readings of female objectification and to engage with a 'different way of knowing' that is presented in the character of Wonder Woman.

Overall, this 'different way of knowing' is a comfortable playground for ANT's lens of semiotic relationality. Wonder Woman, as portrayed in Destiny Calling, is an ideal canvas to think with ANT's theoretical tools and interests, which include tracing translations and ontologies of co-production and exploring generative multiframes. Positioning comics as effects co-produced between contexts, political environments, scripts and technologies allows us to critically engage with these stories with fluidity and flexibility. Consequently, we are able to play with the different ways of knowing Wonder Woman and test the complex boundaries and intersections enabled by a historical and performative tracing of the Wonder Woman mythos. Following John Law, we leverage the way in which 'ANT's single minded commitment to relationality enables the exploration of strange and heterogeneous links and to follow surprising actors to equally surprising places'. 5 Thus, in this exploration we provide a brief overview of an ANTish approach, argue why ANT enables an exploration of the theoretical construction of Aristotle's justice, situate Wonder Woman as an effect of an emerging and fluid socio-cultural assemblage and finally, explore the comic vignettes offered in Destiny Calling as potential performances of 'complete virtue'.

\section{ANT-ish Thinking}

John Law (2007) suggests that ANT is a way of telling or finding interesting stories. We agree. We further note that any overview of ANT literature is a type of betrayal. It sends the wrong message, as it suggests that ANT can be summarised or contained. However, there is a need to familiarise readers with ANT's origins and sensibilities which include intentionally slippery and ephemeral relations and the proposal of multiple realities. The origins that we are enlisting begin with innovations in the Sociology of Science or Science and Technology Studies (STS) 'spawned in the 1970s. ${ }^{6}$ These incursions into laboratories and coffee rooms filled with scientists were equally motivated by a desire to seek 'social' explanations for science and a desire to contest scientific method's monolithic hold on knowledge making. Woolgar (2004) proposes that the origins of STS were around provocations and raising 'profound questions about the very basis of social science' and the theoretical tools employed to do this work included 'perspectives such as relativism, social constructivism, social shaping, ANT, and reflexivity." ANT's evolution from/within STS entailed its taking the position of challenging asymmetric assumptions about the various characteristics of science and technology practices, such as science knowledge production and social institutions, true and false knowledge, the observer and the observed and most significantly, the human and non-human divide. ${ }^{8}$ In short, ANT emerged from a confluence of ontological questions about post-structuralist and post-humanist reinvestigations of approaches to science. For ANT, 'the presumption of essentialism is displaced. Attributes of scientific facts and technologies are then to be understood as emergent properties of network relations between heterogenous entities. ${ }^{9}$

As Adams ${ }^{10}$ and Thompson (2016) note, ANT is an invitation to engage in 'our intimate and co-constitutive entanglements with our technologies as well as with the natural, pre-given world and its creatures ... to take seriously what is most near to us: the everyday thinking of our world.' ${ }^{11}$ This suggestion is helpful, as it indicates that ANT can be seen as a way to dialectically

\footnotetext{
${ }^{4}$ Giddens, On Comics and Legal Aesthetics, 1.

${ }^{5}$ Law, "Actor Network Theory," 7-8.

${ }^{6}$ Callon, "Actor Network Theory," 62.

${ }^{7}$ Woolgar, "What happened to Provocation?" 340.

${ }^{8}$ Woolgar, "What happened to Provocation?" 343.

${ }^{9}$ Woolgar, "What happened to Provocation?" 344.

${ }^{10}$ Researching a Posthuman World.

${ }^{11}$ Adams, "Interviewing Objects," 5-6.
} 
uncover the taken for granted nature of the networks of technologies, texts, gestures and characters on the pages of comics. Ultimately, at its most fundamental level, ANT is a way of conceptualising the relations or interactions between things (both non-human and human) as co-constructed. It places a generative lens on comics. The comic superhero genre becomes through actors, such as backdrops and settings, villains, social norms, superpowers, readers, weapons, white space, coloured pixels, symbols and their relations or networks between each other. Every actor in these networks connects to an equally complex and inexhaustible network of their own. Put more simply, comics are networks in networks in which associations are everything. These 'associations involve physically co-present humans, artefacts, environments and congealed past actions or scripts.' ${ }^{12}$ For comics, the inclusion of ideas of congealed past actions or scripts can be very productive. In this paper, the examination of such ideas will help us to theoretically navigate the assemblage of the powerful female character that emerged from the mind of William Moulton Marston, who is well known for his belief in women's empowerment. ${ }^{13}$ However, it should be noted that Marston's shape of empowerment included 'rosy cheeks, bouncy curls, [an] hourglass figure and a penchant for thematic lingerie,' which interestingly, reflects how Frank ${ }^{14}$ described the evolution of the pin-up girl. This vision is contrasted with the equally viable aesthetic connections to the progressive possibilities of the mythic Amazons or suffragettes as female agents for social change. Through her perfect skin and body, revealing outfit and defensive weaponry, Wonder Woman has emerged to bear the burden of a man's world. This configuration of power is disruptive.

ANT loves disruption. We stated this above; however, it is an important point to emphasise. ANT requires an unusual attention to detail. All the mundane, insignificant, uninteresting and often overlooked parts form part of the ANT lens. ANT tells us that small things matter, which is not news to Ant-Man or evil nuclear physicists. However, ANT does more than open up our empirical practices to include everything from the micro to the mundane; it presents a controversial idea; that is, that all these things, human and non-human, from 'pauper to king' should be treated equally - generalised symmetry. Callon (1986) introduces this concept explicitly in his paper on scallop aquaculture and indicates it is a response to the conspicuously asymmetrical texts that were emerging from sociologists in which scientists and engineers are depicted working through problems of nature set within the existence of social norms. Callon objected to the idea that scientists could practise the 'scientific method' in a vacuum in which a few could explain the many. As Callon lamented:

Science and technology are dramatic 'stories' in which the identity of the actors is one of the issues at hand. The observer who disregards these uncertainties risks writing a slanted story which ignores the fact that the identities of actors are problematic. ${ }^{15}$

We recognise that everything about the Wonder Woman assemblage is problematic, including the key actor that is the skimpy swimsuit outfit. The invitation that ANT offers is to consider that the pictorial configurations on the page are products of multiple sets of relations and have layered and at the same time, emergent (not set or determined) effects. In applying ANT, we can move past the bold or more obvious configurations related to the sexualised body of Wonder Woman to think about what else is offered by these swimsuit configurations. What is the performance? What is being done? Ultimately, Wonder Woman is a multifaceted and problematic figure in this milieu that enrols both ancient and contemporary narratives, complex assemblages of godlike powers and is caught in the perpetual conflagration of envy, power and malevolent forces. Thus, it is our contention that Wonder Woman is best understood as a network effect. Further, it is the extreme nature of her network associations that allow her as a character to demonstrate the most complete version of Aristotle's sum of all virtue-justice.

\section{Why ANT and Why Aristotle?}

When talking about the performative nature of virtue Aristotle explains,

$\ldots$ as in the Olympic Games, it is not the most beautiful or the strongest that are crowned, but those who compete. ${ }^{16}$

The decision to combine ANT and Aristotle for this exercise was purposeful and was based on the common ontology of becoming. ${ }^{17}$ Aristotle himself articulated that virtue cannot be defined by an act, rule, person, place or time, as it evolves out of all these dimensions. Thus, for ANT and Aristotle, the network and the performance matters. We argue that complete virtue manifested as justice is a class of performance of its own. The performance not only relates to acts of justice, but also demonstrates the sum of all virtues, including courage, love, loyalty and service. To understand what interactions would encapsulate the sum of all virtue, it is necessary to think about the basic tenets of Aristotelian virtue. First and foremost, virtues are multifaceted and encompass both intellectual or rational attributes, which 'are owed to birth and growth to teaching,' and

\footnotetext{
${ }^{12}$ Nespor, "Devices and Educational Change," 16.

${ }^{13}$ Lepore, Secret History of Wonder Woman.

${ }^{14}$ Frank, "The History of the Pin-Up Girl."

${ }^{15}$ Callon, "Some Elements of a Sociology of Translation," 3.

${ }^{16}$ Aristotle, Nicomachean Ethics, 13.

17 Waelbers, "Ethics in Actor Networks."
} 
moral characteristics, which emerge from habits. ${ }^{18}$ Aristotle describes virtue as human perfections that are socially situated and must be purposely cultivated through action and access to the external goods or the 'proper equipment.' ${ }^{19}$ Ultimately, virtues are manifested through capacities that must be practised, as stated by Aristotle:

For the things we have to learn before we can do them, we learn by doing them, e.g., men become builders by building and lyre players by playing the lyre; so too we become just by doing just acts, temperate by doing temperate acts, brave by doing brave acts. ${ }^{20}$

Second, virtues are performances within emergent contexts and settings. These contexts and settings are the opportunities or the 'fields of action' afforded by the mingling of people and things. Thus, the configuration of virtue includes both capacities and opportunities for action in relation to others. Third, virtues are defined by the wisdom of finding the mean between excess and deficit in action. The following quote illustrates how Aristotle explores at length the possibility of "the nature of actions and how we ought to do them.' 21

First, then, let us consider this, that it is the nature of such things to be destroyed by defect and excess ... So too is it, then, in the case of temperance and courage and the other virtues. For the man who flies from and fears everything and does not stand his ground against anything becomes a coward, and the man who fears nothing at all but goes to meet every danger becomes rash; and similarly the man who indulges in every pleasure and abstains from none becomes self-indulgent, while the man who shuns every pleasure, as boors do, becomes in a way insensible; temperance and courage, then, are destroyed by excess and defect, and preserved by the mean. ${ }^{22}$

He also suggests that guidance or rules for conduct can only be given as an 'outline' or in a non-precise nature, as every situation will have nuances and complexities that cannot be captured in a defined, fixed or set manner. The outline that Aristotle offers is the concept of a continuum of action from deficit to excess that is both fluid and contextually framed where no two continuums are equivalent.

The question raised in this paper is: What type of configuration of superpower would allow for the pinnacle demonstration of complete virtue as justice? Arguably, all superheroes have capacity, opportunity and time. They are scripted into being to right the wrongs of villains and monsters. Arguably, their performances are less admirable, as their bodies, powers and identities give them capacities and opportunities that make it easy to do good or perform virtuously. However, such logic is faulty, as the greater the powers the greater the test or continuum of choice. The vice of superpower is axiomatic. It could make superheroes unrestrained, egotistical, unaccountable or impertinent. Indeed, the intoxication of unlimited power has certainly turned many a 'good' actor 'bad'. Aristotle suggests that virtue and vice are concerned with pleasure and pain and that the development of the right associations between virtue and pleasure is difficult for any human or superhero. Aristotle further notes that 'to feel delight and pain rightly or wrongly has no small effect on our actions. ${ }^{23}$ Thus, the configuration we seek must actively develop the right associations with pleasure, which is a challenging path.

Finally, Aristotle suggests that 'the good is even better when it is harder.' ${ }^{24}$ This simple statement is key to the architecture of our argument. Critically, the demonstration of complete virtue moves from doing 'good' or 'evil' acts in the classic comic hero tropes towards a progressive and difficult sequence of performances that are centred on the total amelioration of injustice. This actor-network would seed and sustain a fundamental transformation towards eudaimonia (happiness) or an aspirational state of human flourishing. This is not to diminish the doing of 'good' acts, such as subduing an evil villain; however, it does transcend the dichotomous field in which 'good' is defined by struggles with 'evil' towards the more strategic endeavour of creating a better world. Eudaimonia is a not a personal endeavour; rather, it seeks happiness for the whole of society or societies in which each member has the potential to serve and contribute to the creation of a just world. Arguably, our Aristotelian superhero would not be satisfied with singular acts of vanquishing evil; rather, she would be driven to conduct herself in such ways as to proliferate good.

This description of the emergence of virtue through continuums in a dynamic socio-material network is kindred to ANT's view of life worlds as 'continuously generated effects of the webs of relations within which they are located.' ${ }^{25}$ This is ANT's

\footnotetext{
${ }^{18}$ Aristotle, Nicomachean Ethics, 20.

${ }^{19}$ Aristotle, Nicomachean Ethics, 13.

${ }^{20}$ Aristotle, Nicomachean Ethics, 21.

${ }^{21}$ Aristotle, Nicomachean Ethics, 22.

${ }^{22}$ Aristotle, Nicomachean Ethics, 22.

${ }^{23}$ Aristotle, Nicomachean Ethics, 24.

${ }^{24}$ Aristotle, Nicomachean Ethics, 24.

${ }^{25}$ Law, "Actor Network Theory," 2.
} 
playground, a place in which effects, such as virtues, can be traced by delicately following the actors and thinking through socio-material relations. For this exploration of Wonder Woman in Destiny Calling, we enrol gods, humans, offices, desks, turtlenecks, name badges, monsters and swimsuits to explore the emergence of virtue. However, it is not just any virtue that we wish to trace; it is the culmination of all virtue - justice. Aristotle suggests that justice is the 'greatest of virtues,' notes that 'in justice is every virtue comprehended' and states that justice is the 'actual exercise of complete virtue. ${ }^{26}$ He notes that 'he who possesses it can exercise his virtue not only in himself but towards his neighbour.' ${ }^{27}$ This configuration of justice as complete virtue is multifaceted, concerned with the pleasure and pain of others and lies in a mean on a continuum where, as we noted above, the demonstration of the 'good is better when it is harder.' ${ }^{28}$ It is in this complicated, fluid and multidimensional configuration that we employ ANT. Our task is to demonstrate how this could occur in the pages of Destiny Calling. However, before we do this, let us first examine the histories and evolving character of Wonder Woman as an assemblage more closely.

\section{A Short History of Wonder Woman}

Pérez begins Density Calling with an origin story of Wonder Woman:

Over three thousand years ago, the goddess Artemis proposed to the Olympian gods that a new race of mortal human beings be created, which she would call Amazons - a female race that would set an example for the rest of humanity and promote equality between the sexes ... On Artemis' instructions, Hippolyte formed the image of a baby from the clay of Paradise Island. The five goddesses who were the Amazon's patrons, along with the god Hermes, endowed the unborn soul with various gifts, including super-human strength and speed and the power of flight. ${ }^{29}$

This story includes a collision between gods, clay, time scales, myth, emergent feminism and the telos of creating the ideal society. The original character was created by Marston, drawn by Harry G. Peter and first appeared in Sensation Comics \#1 in January $1942 ;{ }^{30}$ however, it should be noted that the character was first previewed in All-Star Comics \#8, which appeared slightly earlier. ${ }^{31}$ The first element in this original translation is that Wonder Woman is an Amazon. The very term 'Amazon' is charged with complex politics. In Greek mythology, the Amazons formed a matriarchal warrior society. Unmarried and unconquered, the Amazons were a threat to the order of patriarchal Greek society. Traditional Greek myths contain stories of incursions on Amazonian territory, including Heracles's (Hercules's) sexual defeat or rape of Hippolyte, which was symbolised by his taking her girdle, and Theseus's rape of another Amazonian queen, Antiope. In the $16^{\text {th }}$ and 17 th centuries, the term 'Amazon' was also used to refer to the uncivilised and dangerous 'New World' and was used to help legitimise its colonisation. As Clare Pitkethly (2012) notes, the characterisation of Wonder Woman as an Amazon was thus a very powerful inversion of the usual Western trope regarding the nature of femininity and heroes/heroines. ${ }^{32}$ Marston chose this term precisely because it was already in use among the suffragist and Bohemian women he knew. According to Jill Lepore, the term 'Amazon' was used by early feminists and referred to 'any woman rebel' who was opposed to patriarchy. ${ }^{33}$

The connection with the shifting Amazonian mythos is not the only fluid part of the Wonder Woman assemblage. Another important fluctuating element in her origin story is her birth. Originally, Wonder Woman was brought into the world through an all-female birth; she was made from clay by her mother, under the guidance of Artemis and given 'the divine gift of life' by Aphrodite. ${ }^{34}$ Not a man was in sight. It is hard not to see this as representing a vision of women having complete control of reproduction. Such a reading is amplified given that we know that Marston's lover, Olive Byrne, who lived in a polyamorous relationship with Marston and his wife, Elizabeth Holloway, was the niece of Margaret Sanger, the founder of Planned Parenthood in the United States (US). Lillian Robinson further extends the significance of this origin story, arguing that it is also a radical engagement with Biblical myth and noting that Marston has 'invent[ed] a female deity who has the power attributed to the God of Genesis. ${ }^{35}$

In Destiny Calling, the volume considered in this paper, George Pérez adds a further element to this gender politics by acknowledging the scourge of domestic male violence. In a faithful reworking of Marston's origin story, he depicts the Amazons emerging from a sacred pool, reanimated with the souls of women who had been killed at the hands of violent men.

\footnotetext{
${ }^{26}$ Aristotle, Nicomachean Ethics, 73.

27 Aristotle, Nicomachean Ethics, 73.

${ }^{28}$ Aristotle, Nicomachean Ethics, 24.

${ }^{29}$ Pérez, Wonder Woman: Destiny Calling, 4.

${ }^{30}$ Marston, Sensation Comics.

${ }^{31}$ Marston, All-Star Comics.

32 Pitkethly, The Pursuit of Identity," 217.

${ }^{33}$ Lepore, Secret History of Wonder Woman, 17.

${ }^{34}$ Marston, Wonder Woman.

${ }^{35}$ Robinson, Wonder Women, 29.
} 
These poor souls had been kept safe in a cave known as 'Gaia's womb'. It is interesting to note that in a more recent translation, created by Brain Azzarrello in 2012, Wonder Woman's creation story was changed, such that Zeus was now said to be her father. ${ }^{36}$ This reimaging fundamentally challenges the female-only original assemblage of Wonder Woman and makes her a 'token' of the persistence of the patriarchy at a time when positive changes regarding gender were being seen in the wider genre. $^{37}$

Moving from her birth story and the origins of the Amazons to her physical accoutrements, we find that each piece brings with it a new network of associations. Let us start with Wonder Woman's iconic bracelets, also known as the 'Bracelets of Submission'. These shiny, powerful and bullet deflecting actors enrol an array of relations, including Greek myths, alternative marriages, wounds and war. Materially, they represent the memories of how the Amazons were once enslaved by Hercules only to be freed by Aphrodite, who then commanded that they must wear the manacles (bracelets) as a reminder of 'the folly of submitting to men's domination.' ${ }^{38}$ When Robert Kanigher took over the writing after the death of Marston, his translation once again tested the ideas or roles associated with a super-woman. Indeed, at one point, he made Wonder Woman the secretary of the Justice League. The story of her bracelets also continued to morph, such that they were later said to be made of Amazonium, thereby creating a material link to the Amazons' home on Themyscira. ${ }^{39}$

Destiny Calling positions the bracelets as a key actor and continues to shift the original translation in which Pérez presented Athena as the goddess who freed the Amazons, explaining to Hippolyte that she was enslaved because she betrayed her mission and purpose. ${ }^{40}$ Wonder Woman's bracelets become the last remnants of Aegis, 'the impenetrable shield formed from the hide of the Great Goat Amaltheia, who wet nursed the infant Zeus and thus provided the energy from which Olympus sprung. ${ }^{4}$ The bracelets remain both a powerful shield and a message of the dangers of Man's World to women. Beyond the shifting mythos, the bracelets follow and translate the complex constellation of gender and sexual politics of the time. They also create connections with the regular fashion accessory worn by Olive Byrne, the woman who 'married' Marston and Holloway and who is part of the 'real-life' inspiration for the Wonder Woman character. ${ }^{42}$

Related to this theme of submission and freedom is the 'Lasso of Truth'; a technology frequently used in Pérez's volume. Early Wonder Woman did not carry her famous lasso. It only emerged in 1942 in Sensation Comics \#6. In the very same month, it was retconned into her origin story in Wonder Woman \#1. In Marston's story, the lasso is made from Aphrodite's girdle and forged by an Amazonian smith called Metala. Conversely, in Pérez's version, it is forged in the fires of Hestia (the goddess of the hearth, fire and thus the most fundamental technology) from Gaea's girdle by Hephaestus. In evoking these most powerful goddesses, Pérez makes the gender politics of the lasso even more powerful. The lasso compels anyone bound by it to tell the truth; however, it has also been used to restore memory, enable teleportation, translate languages, remove illusions, protect those in its circle, help Wonder Woman change costume, administer therapy, move the Earth back to its natural orbit ${ }^{43}$ and brainwash Judy Garland. ${ }^{44}$ Equally, the lasso relates materially to Marston's work as a psychologist who created the lie detector. A quick scan of the Internet reveals numerous pictures of women tied up with Marston's lie detector equipment.

The lasso, like the bracelets, was originally linked to submission; whomever Wonder Woman tied up with the lasso was obedient to her. The lasso and the bracelets were integral to the practice of bondage for which the early Wonder Woman comics were infamous; however, the intention behind such images was not simply titillation. Focusing on Marston's academic writings in psychology, Ben Saunders has shown how the images of bondage are rooted in Marston's research on the link between sexuality and politics. According to Saunders, Marston believed the social construction of men's sexuality confuses love with appetite, compelling them to primarily seek pleasure from domination. ${ }^{45}$ The sadism of World War II was, for Marston, indicative of this trait. To counter this, freedom and peace were to be sought via pleasure in submission. Further, women, who Marston believed were socially constructed to take pleasure from both submission and domination, have the capacity to act as agents of social change and become what Marston called 'love leaders' in 'a utopian project of "Emotional Re-Education.",46 As an important aside, it should also be noted that Wonder Woman's relationship with chains is another strategic link to the women's suffrage movement. For example, Lou Rogers's 1912 cartoon, entitled 'Tearing Off the Bonds', depicts a woman

\footnotetext{
${ }^{36}$ Azzarrello, Wonder Woman.

${ }^{37}$ See Curtis, "Superheroes and Third-Wave Feminism," 2017 and Curtis, "Wonder Woman's Symbolic Death,” 2017.

${ }^{38}$ Marston, Wonder Woman, 5.

${ }^{39}$ Kanigher, Wonder Woman.

${ }^{40}$ Pérez and McLeod, Wonder Woman, 19.

${ }^{41}$ Pérez, Wonder Woman: Destiny Calling, 18.

${ }^{42}$ Lepore, Secret History of Wonder Woman, 143-144.

${ }^{43}$ Kelly, Justice League of America.

${ }^{44}$ Pasko, Wonder Woman.

${ }^{45}$ Saunders, Do the Gods Wear Capes, 49.

${ }^{46}$ Saunders, Do the Gods Wear Capes, 50.
} 
breaking ropes wrapped around her that read, 'Politics is no place for women. ${ }^{47}$ Peter, the artist employed by Marston to draw Wonder Woman, was expressly chosen because of his connection with Rogers and his own 'experience drawing suffrage cartoons' in which being bound and breaking chains was a recurring trope. ${ }^{48}$

The next actor is Wonder Woman's tiara. Originally, Marston and Peter had designed it to represent both Amazonian and American nobility, as the nation tasked with defeating the sadism and tyranny of the Nazis. Notably, the tiara represents Wonder Woman's Amazonian royal status as the daughter of the Queen. It is part of the costume that Hippolyte gives to Diana when she wins the competition to determine which Amazonian champion will be sent to Man's World. The tiara also functions as a cue that Wonder Woman is a princess in Man's World. As a princess, she wears an outfit that is distinctive, exceptional and other worldly.

Interestingly, one of the most intriguing aspects of Pérez's translation is the way in which he reworked the origin of the costume, particularly in relation to the final form that the tiara takes. In Marston's origin story, the Amazons are motivated to send someone back to Man's World because the US pilot, Steve Trevor, has been shot down and forced to crash-land in the waters off Paradise Island. Conversely, in Pérez's version, Trevor arrives at Paradise Island much later in history, having been manipulated by Ares to attack it. The member of the Trevor family that first arrives is Steve Trevor's mother, Diana Rockwell Trevor, who is also a pilot. She was a member of the Women's Auxiliary Ferrying Squadron (WAFS) during World War II. At the time at which she crashed at Themyscira, she was flying jets for the US Air Force. In the story, she wears a jacket bearing the US flag and a WAFS patch and badge. After the crash, she is immediately thrown into a battle with a violent monster called 'the Cottus' that is threatening the life of the Amazons. She kills the monster but dies in the process. She becomes a hero to the Amazons and her uniform accoutrements become the inspiration for the Wonder Woman costume. In addition, Hippolyte honours Trevor by naming her daughter Diana. Notably, Pérez presents the gold tiara displaying a red star in honour of Diana Trevor, who wore a star on her jacket. The star also enrols a visual echo of the wound we see just above Diana Trevor's forehead in the final image before her death. In this translation, the primacy of women and goddesses is strengthened. Pérez explicitly draws on the subjugated history of women pilots in World War II whose commitment, skills and bravery made a significant contribution to the feminist movement. In this version, Wonder Woman's tiara becomes the spokesperson for a multitude of others.

Arguably, the most salient actor in Wonder Woman's assemblage is her suit, which enrols a complex array of ancient Greek iconography, feminist ideals and a heterogeneous cultural network of sexist and objectifying performances. When Marston and Peter first visualised the character, she was wearing a pair of sporty knee-length culottes that emulated the skirts worn by mythical Amazons in classical Greek works of art. Amazons were often depicted semi-naked and it would appear that Wonder Woman's bodice was an adaptation of the body armour known to have been worn by Greek warriors that left arms and shoulders naked. Another important visual tributary would have been the style of 'good girl' art in comics that was popular with men in the Armed Forces during the 1940s. It should be noted that this style increasingly influenced the representation of female superheroes until, finally, this 'good girl' style transitioned into the 'bad girl' style of the 1990s in which bodies were elongated and the female form was exaggerated in hyper-sexualised poses.

Notably, there was a campaign to have Diana's powers and costume returned after she lost them in 1968. Most vocal in this regard was Gloria Steinman who also used an image of the re-powered (and larger than life) Wonder Woman on the cover of the first standalone issue of Ms magazine in 1972. This version of the costume was also built from the genre's mode of transmedia storytelling and influenced by the 1973 animated cartoon, Super Friends, and the glamourous 1975 television show starring Linda Carter. However, one specific difference in Pérez's costume was the now famous winged double 'W' logo designed by Milton Glaser in 1982. This logo was introduced as DC became ever more aware of the role of branding in their superhero franchises. For the present paper, the amount of skin revealed by what ultimately became little more than a swimsuit is key. This suit-body assemblage pulls in classical Greek representations of Amazons, extreme bodies, athleticism, strength, beauty, sex and pleasure.

\section{Detecting Complete Virtue-Justice}

The next three vignettes, which are taken from Destiny Calling, provide spaces through which we explore the emergence of complete virtue with an ANT-ish lens. We have chosen three markedly different scenes that enrol different assemblages of actors and histories that we feel exemplify vastly different performances of virtue. These vignettes are presented in the order in which they appear in the collection and can ultimately be viewed as an entangled and cumulative emergence of complete virtue. Each vignette builds a fuller understanding of Wonder Woman in the world and connects each virtuous performance as being

\footnotetext{
${ }^{47}$ Lepore, Secret History of Wonder Woman, 85.

${ }^{48}$ Lepore, Secret History of Wonder Woman, 194.
} 
situated along a continuum of choice between deficit and excess. In each of Enrolling Mount Olympus, An Office Visit and The Test of Hermes, Wonder Woman's assemblage of a swimsuit, a tiara, bracelets, boots and a lasso are brought forward as coactors in the pursuit of the good and the pursuit of complete virtue-justice.

\section{Enrolling Mount Olympus}

Wonder Woman's destruction of the remnants of Mount Olympus is the first vignette in which we investigate the emergence of complete virtue as a mean along an exaggerated continuum of virtue and vice. This performance includes a network of actors, including a dying mountain, a paradise lost, evil spells, a plethora of Olympians, the collection of veiled beautiful Amazonian worshippers, ancient wisdom, multi-worlds, leaps of faith and the affects of doubt, anger and dissention, generated by Hermes. All these context-setting agents become the background for Wonder Woman's performance. She is requested by the gods to right a significant wrong perpetuated by the cosmic super-villain, Darkseid, in an earlier event that destroyed much of Mount Olympus and left behind a horrible heap of rubble and the evil marks of decay, destruction and disorder. Diana is given the task of destroying the last remnants of the mountain so that 'the fire of its destruction shall light the torch of a new Olympus.' 49

In short, this monumental task summarily produces a cogent model of complete justice. It requires much more than an act of superpower strength and finesse. As we believe Aristotle would argue, superheroes have trouble demonstrating courage because they have extraordinary powers that limit their chances of failure. Courage is only truly demonstrated when the odds are against you and you can taste the fear of death. ${ }^{50}$ In this sequence, Wonder Woman must call on multiple virtues, including courage, against unknowable odds, for an unknown and uncharted future. This is a 'sphere of human existence' that marks out the terrain for the performance of complete virtue. ${ }^{51}$ The request from the gods is offered as a choice and her possible response to this request lies along a continuum, from apathy, insolence and disrespect to a heroic and irresponsible hubris of strength and foolhardiness. A glimpse of what complete virtue could look like arises from the culmination of her actions, intentions and stated motivations as depicted in this impossible assemblage.

It is important to recognise that the destruction of Mount Olympus represents both a psychological and physical task. It essentially dismantles and raises questions about Wonder Woman's role and purpose as an Amazon. She was brought up to protect, love, serve and dedicate her life to the gods who in turn have made her life and the world of Themyscira possible. She is then asked individually and solely on the basis of faith and trust to sever that connection. In short, she is asked to give up on all in which she once believed. In addition, the foibles of the gods are revealed to her. She becomes aware that it was the gods' own infighting and lack of action that put the Amazons at risk by exposing them to an attack from Circe. In each frame in this chapter, Wonder Woman is tested with a sequence of shattering revelations that disturb what she thought and believed to be true about the world. In every moment, she takes the new information in stride and adjusts to the new realities laid out before her. This culminates in her ultimate sacrifice and her performance of duty and bravery.

Ultimately, we find her, disrobed, bare shouldered in her swimsuit armour, standing resolutely on an evil rock protrusion marked by the scars of Darkseid. As the gods look down on the small feminine body of Wonder Woman, clad only in her bracelets, swimsuit, boots and lasso, she is asked to withstand the charge of the combined power of the gods and the prayers of the Amazons. She performs the deflection of the cosmic force (which has an unfortunate phallic look to it) using her bracelets with a mixture of what looks like ecstasy, remorse, fear and resignation. The suit highlights her female form and juxtaposes it to a backdrop of evil, male dominance, corruption and desperation.

In this extreme performance, she becomes the medium between the old and the new and the channel through which the past becomes the future. She ultimately facilitates the cosmic migration of the gods in their mission to establish a new Olympus. In this moment, Wonder Woman stands alone, bare shouldered, in her suit, bracelets, tiara and boots and does a job that no god or man alone could do. These actors translate, shape and mediate her femininity, her vulnerability and her objectified self. It is through these tools of meekness, immoderation, pleasure and vanity that Wonder Woman demonstrates a complete justice, a justice of godlike proportion, that ultimately models the best of what we can be-blind or impervious to vice-and how we can pursue virtuousness against a backdrop of injustice that is both excessive and extreme in its violence and oppression. On this page, Wonder Woman obediently serves the fallible gods in the destruction of Mount Olympus, a place she held sacred and to which she dedicated her life's work and prayers to sustaining. She is called to make this ultimate sacrifice-a sacrifice of unequalled proportion and a demonstration of surpassing power-and performs this challenge to support their eventual cosmic

\footnotetext{
49 Pérez, Wonder Woman: Destiny Calling, 47.

${ }^{50}$ As Aristotle stated in, Nicomachean Ethics, "Properly, then, he will be called brave who is fearless in the face of a noble death," 45.

${ }^{51}$ Nussbaum explains that Aristotelian virtue does not occur in neatly defined boxes but rather in what she calls "spheres of human existence" or contexts. This approach allows virtue theory to evolve as these conditions or spheres exist beyond histo-cultural or technological boundaries; see Nussbaum, "Review: Comparing Virtues."
} 
migration. Ultimately, Wonder Woman's performance is not impressive for its physical strength but for the moral perfections embodied through her assemblage. She has melded both noble thoughts and actions and she has offered to right the wrongs of others for others. This exercise for 'another's good is virtue in the fullest sense. ${ }^{52}$

\section{An Office Visit}

Moving from the overpowered and astounding task of decimating Mount Olympus, the next vignette highlights a key assemblage that demonstrates Wonder Woman's diplomacy, respect, humility and modesty in Man's World. As in the previous vignette, this sequence is a translation of a complex collection of actors, including the Great Gynocracy, a proclamation, sacred gardens and shrines, physical memories of Hades, sacrifice in battle, trauma associated with rape, imprisonment and forgiveness. It opens with Wonder Woman delivering the results of a vote to her sisters that will allow men to step foot on Themyscira. A step which represents a staggering new phase in the world of the Amazons. Next, she is shown consoling Hellene, who is doubtful of the prospects of this new venture. In this beautiful and touching scene, Hellene reminds her of the sickness that plagues Man's World, describing it as a sickness that has 'weakened and corrupted us' and 'chained and violated us.' Wonder Woman, in her suit, calmly extols the virtues of thinking critically and challenging decisions. In doing so, she balances Hellene's fear with her own indomitable belief in the good of mankind and the good that Amazons can share with this world.

Wonder Woman becomes the liaison between the two worlds and is given the task of deciding who the first visitors from Man's World will be. She selects Julia and Nessie, whom she excitedly swoops down and lifts them, while still in their car in traffic, and flies them home. This demonstration of humorous superpower, strength and excitement reveals that Wonder Woman is bursting with anticipation and joy at the chance of sharing her homeland and family with her human friends. This act sets the scene for her next visit, which is a true test of her ability to virtuously manage her superpowers. She then flies to the Hanscom Airforce Base where her friend Etta works.

As the scene unfolds, we see Wonder Woman's respect for and willingness to work within the bureaucracy of Man's World. After arriving at the base in her outfit, she is required to follow a sequence of absurdly civilian moves, including making an appointment, obtaining a security pass and pinning it to her outfit (as if her identity could be questioned), waiting patiently for a secretary to announce her wish for a meeting, meeting General Hillary, sitting down in a small office chair across from a large desk covered with banal office adornments and finally, submitting her request, which is then summarily denied. This is an assemblage of Kafkaesque rules that includes details of the unnecessarily frustrating nature and bewildering logic of officialdom. Wonder Woman is treated both as a military equivalent — a fellow warrior — and a potential leak and thus someone untrustworthy.

This compromising situation represents a significant test for Wonder Woman. Her potential actions easily span a continuum from incontinence of indignation, rage and outbursts of bewildering frustration to extreme resentment that manifests in her making immodest claims about her stainless character and record and her displaying proof of her intellectual superiority and disproportionate superpower. With all we know about Wonder Woman, how could General Hillary treat her this way? How could she withstand the absurdity of this situation? In one lightning move, she could have taken out her lasso and in the next, she could have retrieved the information about the location of her friend Lieutenant Candy and the project on which she is working. What does she do in this assemblage of actors? She does not argue or try to sway the General to her logic. She does not explain that her role in Man's World is to be an ambassador, that she has a duty to protect and that she is trustworthy; rather, she chooses to accept the General's will without question.

We next see her standing in the office in her swimsuit to which she has pinned her security pass. Her princess tiara sparkles, the magic lasso of truth is at her hip and her wrist bracelets gleam. She has just deflected the most powerful force in the universe, but refrains from extracting any information from a hubristic General at a local air force base. The reader may wonder what type of secret mission Etta could be on? What type of mission is so top secret that the heroic and sworn protector of Man's World could not know or manage that information? How could Wonder Woman pose a risk to the integrity of that mission? Despite the ridiculousness of the scenario, we must ask what this interaction tells us about Wonder Woman? It tells us a great deal. It tells us that despite Wonder Woman being stronger, faster, smarter, more able, more beautiful and purer in motive, she is prepared to diplomatically live by the norms and rules of Man's World. She is prepared to follow orders and accept illogical human rationalisations and processes. She acquiesces to a bureaucratic and patriarchal system that sees women as secretaries who open doors and men as leaders who make decisions.

\footnotetext{
${ }^{52}$ Aristotle, Nicomachean Ethics, 73.
} 
The one image that stands out in this sequence is the handshake between Wonder Woman and the General. The gleaming bracelets, which just performed the extreme feat of starting the cosmic migration of the gods, are now gracefully accepting orders from a man in the military. It is a spectacular performance of humility and sacrifice of an entirely unprecedented nature. Wonder Woman recognises that she lives in an imperfect patriarchal world. In her performance, she rises above the simplistic instincts of having power over others. She decides that if she is going to make a difference in Man's World, she must do it in her own way, through diplomacy, respect and humility. It is an act of nobility and complete virtue; it is an unparalleled act of justice.

\section{The Test of Hermes}

This final vignette highlights the role of Wonder Woman in bridging the multiworld and managing an extreme case of prodigality and base desires. In chapter five, the story returns to Hermes who believes that the gods do not do enough to warrant devotion and faith from humans. To rectify this he decides to make a very public visit to the human world 'to let all humanity feast their eyes upon the glory and spectacle of an Olympian. ${ }^{53}$ For Wonder Woman, this chapter enrols the media, money, malevolent monsters and the extreme trappings of narcissism. This is juxtaposed to her humility and sworn pledge to teach peace, love and equality. The actors in this assemblage work to test and highlight the effects of justice and temperance. Hermes is shown embracing excess, lavishly showering gold coins on anyone who gathers around him. He is depicted as being completely devoid of any virtue and unaware of the potential blindness that develops from self-interest and the corruption that arises from a love of money and power. Equally, Phobus and Ixion are presented as pure evil with no sense of humanity, shame or conscience. This conflagration of vice provides the background against which Wonder Woman serves as a model of complete virtue and an example of justice found in the mean between excessive narcissism and complete hatred and disregard for life.

Hermes is shown falling victim to his own blizzard of self-aggrandisement in which there is no room for logic, moderation or caution. This void of reason allows him to become a target of a young woman called Eury, who prostrates herself and charms him by speaking Ancient Greek and asks for his help with her dying father. Flattered by her gushing adoration, Hermes visits her father. Unfortunately, this is a trap. Eury is actually Euryale, a Gorgon, and the old man lying on the bed is really the villain, Phobus, who revitalizes himself by holding onto and absorbing power from Hermes' Caduceus staff, which represents his role as the messenger of the gods. Phobus then uses the staff to release a monster known as Ixion the Assassin.

Unaware of the havoc Hermes's arrogance and lack of judgement is causing, we find Wonder Woman at the temple that Hermes has erected for himself in the 'woodlands of New Hampshire.' ${ }^{54}$ We see her take refuge from the 'confusion and conflict' of recent days by taking a swim in a lake (in a different swimsuit costume). As she dives into the lake, we see her body silhouetted against the moon, which is an important aspect of the mythology of her namesake, the Roman goddess, Diana. This symbol introduces its own collection of actors, as the goddess Diana represents the countryside (in which Hermes's temple stands), the hunt (on which Wonder Woman is about to embark) and the underworld (that has so violently manifested itself in Man's World). As she is literally immersed in nature and surrounded by its beauty and serenity, she is suddenly ripped from this scene by a call of help from Hermes.

Once again, Wonder Woman, in her shiny and feminine costume, is called upon to solve a situation not of her own making. She deftly takes down Phobos and Ixion with her customary finesse, clear thinking, courage and super strength. This storyline explicitly juxtaposes the fallibility or incontinence of the gods to the careful and deliberate approach adopted by Wonder Woman. The fact that Hermes, whose role is to be the messenger and bridge between the gods and humans, was ultimately portrayed as a victim of his own delusionary self-aggrandisement is clear. In the end, it is his excess and lack of insight that invited evil upon the world. Wonder Woman's final expression of justice is the truthfulness with which she admonishes Hermes at the end of the chapter. Delivering this admonishment does not give her any pleasure; she abhors the thought that she needs to speak directly to Hermes in such a fashion. However, she expresses her disapproval because she believes it is right and necessary to do so.

\footnotetext{
${ }^{53}$ Pérez, Wonder Woman: Destiny Calling, 131.

${ }^{54}$ Pérez, Wonder Woman: Destiny Calling, 156.
} 


\section{Conclusions}

Images and text referencing or highlighting Wonder Woman's' near naked feminine body and beauty are commonplace in Destiny Calling:

You heard the man, Queenie. Get your sexy little butt outta here! ${ }^{55}$

She was a goddess, or what a goddess ought to look like. Firm, round curves packed into a tiny, tight, armour plated American Flag. Her hair was a cascade of lustrous black curls bouncing gently off her smooth, tanned shoulders down to the small of her bare, muscular back. Her eyes were shimmering blue pools that you ached to dive into. From her moist, shiny lips came a gentle, sultry voice, flavoured with an accent both exotic and musical. ${ }^{56}$

You! Untie me, you wretched woman! ${ }^{57}$

However, the provocation of this paper is problematising this titillation and thinking beyond these simple configurations. We propose the assemblage of Wonder Woman matters, her suit matters, and what she looks like matters. It is through this assemblage of strength and femininity, of vice and pleasure, of good and evil that the model of complete virtue as justice is explored. We proposed that Aristotelian virtue requires active engagement in the world and is developed through choice along an emerging continuum between a deficit or excess of pleasure and pain. We placed the character of Wonder Woman within a network of female objectification, exploitation, oppression and sexism as assembled on the page and in the creator's mind. This context afforded a closer investigation of the emergence of Wonder Woman in Destiny Calling. She is overtly presented as a sex object with the help of the swimsuit, her athletic, near-nude body, her flowing hair and long boot-clad legs. However, in contravention of or despite these visual cues and material actors, she demonstrates poise, grace, care and unsurpassed humility towards others. Her actions, her words and her small gestures are not sexually imbued. She does not use her beauty as a weapon or to wield power over others. Arguably, she is always focused on service, love and care.

Each panel in the emerging narratives of tests and difficulties presented in Destiny Calling reveals Wonder Woman either in a compromising situation or helping others out of a mortally dangerous scenario. Each page can easily be re-coded through her actions and words as an exemplification of virtue. They cycle through humility, courage, bravery, commitment, fortitude, honour, reflectiveness and honesty. These performances are not difficult to find, but what is so surprising is how these virtuous character traits seem to arise despite her objectification, the sexual references and her submissive behaviour. From this perspective, her assemblage is continually testing her moral, ethical and physical strength as a character of good. She is continually confounded by her pin-up girl outfit and her defensive weaponry, which equally resemble sexual bondage and restraint tools.

The key idea is that all things are relational. ANT teaches us that one can never isolate pure concepts from the socio-technical networks that shape them. ${ }^{58}$ Thus, the exhibition of complete justice is a relational construct that emerges from the page not because of the essential qualities of Wonder Woman but because of the assemblages that she must work with and through. In terms of her demonstration of complete justice in the vignettes that we have offered, we suggest that her being courageous in combating the surge of the cosmic force (Enrolling Mount Olympus) or the behemoth Phobos, god of Terror (The Test of Hermes) is less interesting then the profound way in which she rises above the patriarchal and sexist limits placed on her body and her potential role in Man's World (An Office Request). In total, her performances, which are effects of her complex assemblage, overcome not only villains but the social constructs that diminish her value. She enrols a constellation of all virtues or justice through these complex and multifaceted tests that are placed before her.

Using the Aristotelian practice of thinking through continuums of deficit and excess, we argued that it is these associations of objectification, tools and technologies and the compromising positions, viciousness and violence with which Wonder Woman is presented that afford the starkly opposite demonstration of purity and justice. ANT suggests that technical artefacts have a role in moral outcomes, as they serve as actors that mediate, control, manage or enable action. Objects matter in ethical practice and moral reasoning. Ultimately, the bare shoulders and the suit elicits connections to immoderation, pleasure and vanity that allow Wonder Woman to demonstrate the highest order of virtue-one that contests and transcends the contexts that she encounters and one that lets her virtue shine even more brightly in relation to the vice, ego and malevolence that confronts her.

\footnotetext{
${ }^{55}$ Pérez, Wonder Woman: Destiny Calling, 14.

${ }^{56}$ Pérez, Wonder Woman: Destiny Calling, 19.

${ }^{57}$ Pérez, Wonder Woman: Destiny Calling, 159.

${ }^{58} \mathrm{Gad}$, "On the Consequences of Post-Ant."
} 
If we lean on the Aristotelian principle of proportionality, ${ }^{59}$ Wonder Woman encounters great and extreme difficulties and responds with equally superlative and virtuous responses, such as courage, care, nobility and compassion. Wonder Woman demonstrates virtuous choices and pure motives in transcending the most egregious of character tests-her femininity as a potential weakness and her body as a site of pleasure. Ultimately, this affords the assemblage of Wonder Woman to perform a form of complete virtue as justice. Further, she does this not in spite of her adornments, such as her bracelets, boots and swimsuit, but because of them. Undoubtably, this thought experiment has raised more questions and opened more lines of thought than planned. However, this is a common side effect of ANT-it offers invitations rather than answers. We acknowledge that Wonder Woman is multiple and defies the simplistic frames set out here. Equally, we contend that Wonder Woman is an important and a potent example of complete virtue-justice - in action.

\section{Bibliography}

Adams, Catherine and Terrie Lynn Thompson. "Interviewing Objects: Including Educational Technologies as Qualitative Research Participants.” International Journal of Qualitative Studies in Education 24, no 6 (2011): 733-750.

https://doi.org/10.1080/09518398.2010.529849

Adams, Catherine and Terrie Lynn Thompson. Researching a Posthuman World. London: Palgrave MacMillan, 2016.

Aristotle. Nicomahean Ethics. Translated by W.D. Ross. Kitchener: Batoche Books, 1999.

Azzarrello, Brian and Cliff Chang. Wonder Woman: Blood. New York: DC Comics, 2013.

Callon, Michel. "Some Elements of a Sociology of Translation: Domestication of the Scallops and the Fishermen of St Brieuc Bay." In Power, Action and Belief: A New Sociology of Knowledge?, edited by John Law, 196-223. London: Routledge, 1986.

Callon, Micheal. "Actor Network Theory." In International Encyclopedia of the Social and Behavioral Sciences, edited by Neil J. Smelser and Paul B. Baltes, 62-66. Oxford: Elsevier, 2001.

Curtis, Neal. "Wonder Woman's Symbolic Death: On Kinship and the Politics of Origins." Journal of Graphic Novels and Comics 8, no 4 (2017): 307-320. https://doi.org/10.1080/21504857.2017.1279198

Curtis, Neal and Valentina Cardo. "Superheroes and Third-Wave Feminism." Feminist Media Studies 18, no 3 (2017): 381396. https://doi.org/10.1080/14680777.2017.1351387

Frank, Priscilla. "The History of the Pin-up Girl, from the 1800s to the Present." Huffpost, November 1, 2014. https://www.huffingtonpost.com.au/entry/pin-up-girl-history_n_6077082?ri18n=true

Gad, Christopher and Casper Bruun Jensen. “On the Consequences of Post-Ant.” Science Technology Human Values 35, no 1 (2010): 55-80. https://doi.org/10.1177\%2F0162243908329567

Giddens, Thomas. On Comics and Legal Aesthetics: Multimodality and the Haunted Mask of Knowing. London: Routledge, 2018.

Gilligan, Carol, In a Different Voice: Phychological Theory and Women's Development. Cambridge, Massachusetts; London, England: Harvard University Press, 1993.

Law, John. "Actor Network Theory and Material Semiotics." In The New Blackwell Companion to Social Theory, edited by Bryan Turner, 141-158. John Wiley and Sons, 2009.

Lepore, Jill. The Secret History of Wonder Woman. London: Scribe, 2014.

Kanigher, Robert and H. G. Peter. Wonder Woman, \#52, New York: DC Comics, March 1952.

Kelly, Joe and Doug Mankhe. Justice League of America, vol. 1, \#75. New York: DC Comics, January 2003.

Marston, William Moulton and H. G. Peter. All-Star Comics, vol. 1, \#8. New York: DC Comics, January 1942.

Marston, William Moulton and H. G. Peter. Sensation Comics, vol. 1, \#1. New York: DC Comics, January 1942.

Marston, William Moulton and H. G. Peter. Wonder Woman, vol. 1, \#1. New York: DC Comics, June 1942.

Nespor, Jan. "Devices and Educational Change." Educational Philosophy and Theory, 43 (2011): 15-37. https://doi.org/10.1111/j.1469-5812.2009.00611.x

Nussbaum, Martha. "Review: Comparing Virtues." The Journal of Religious Ethics 21, no 2 (1993): 345-67.

Pasko, Martin and Jose Delbo. Wonder Woman, vol. 1. \#227. New York: DC Comics, January 1977.

Pérez, George. Wonder Woman: Destiny Calling. New York: DC Comics, 2006.

Pérez, George and Len Wein and Greg Potter. Wonder Woman Vol.1: Gods and Mortals. New York: DC Comics, 2004.

Pitkethly, Clare. "The Pursuit of Identity in the Face of Paradox: Indeterminacy, Structure and Repetition in Superman,

Batman and Wonder Woman." Journal of Graphic Novels and Comics 3, no 2 (2012): 215-221. https://doi.org/10.1080/21504857.2011.599847

Robinson, Lillian. Wonder Women: Feminisms and Superheroes. London: Routledge, 2004.

\footnotetext{
${ }^{59}$ Proportionality is important concept for Aristotle and his account of virtue. Key to this concept is the idea that the nature of proportionality is relative and not fixed and thus context and actor based.
} 
Saunders, Ben. Do the Gods Wear Capes? Spirituality, Fantasy, and Superheroes. New York: Continuum, 2011. Waelbers, Katinka, and Phiilipp Dorestewitz. "Ethics in Actor Networks, Or: What Latour Could Learn from Darwin and Dewey." Science and Engineering Ethics 20 (2014): 23-40.

Woolgar, Steve. "What happened to provocation in science and technology studies?" History and Technology 20:4 (2004): 339-349. 